日植病報 $38: 375-380(1972)$

Ann. Phytopath. Soc. Japan 38: 375-380 (1972)

\title{
イネ白葉枯病に関する研究 (I)
}

感染にともならイネ葉の炭水化物, 窒素化合物, リン酸化合物の変動*

$$
\text { 三沢 正 生 }{ }^{* *} \text {. 宮崎栄一郎** }
$$

Tadao MisawA** and Eiichiro MIYAZAKI**: Studies on the Leaf Blight of Rice Plant (I) Alteration of content of carbohydrates, nitrogenous and phosphorus compounds in the diseased leaves

\begin{abstract}
Alteration of content of carbohydrates, nitrogenous and phosphorous compounds in rice plant leaves infected by Xanthomonas oryzae was investigated.

1. In the inoculated leaves, contents of reducing and unreducing sugar slightly increased at the early stage of the infection. Moreover crude starch content increased, while total carbohydrate and hemicellulose-carbohydrate content decreased by the infection.

2. High accumulation of free ammonia, low contents of water soluble protein and water insoluble protein-nitrogen were characteristic of the inoculated leaves. With the progress of the disease, total nitrogen content decreased gradually. According to the results of molecular weight classification of water soluble protein, the contents of high molecular weight protein, especially "fraction I protein", decreased and low molecular weight protein increased by the infection.

3. At the early stage of the infection, increases of acid soluble phosphorus and inorganic phosphorus contents were observed respectively. During the all experimental periods, there were high contents of total phosphorus and insoluble phosphorus in the inoculated leaves.

(Received January 22, 1972)
\end{abstract}

\section{I. 緒言}

従来, イネ白葉枯病についての研究はイネ品種間の 発病差異, 生育時期および施肥法の相違による临病性 あるいは抵抗性の変動 6,21$)$, 発生経過 $2,7,21)$, 病原細菌 の生理 $8,9,13,16)$ など多数の報告がある。しかし病原細 菌侵入後の寄主の生理变化を追求した研究は少なく, 渡辺ら ${ }^{19)}$ の呼吸の変動に関する研究などが主なもの である。また，罹病にともならイネ葉の各種成分の消 長についての研究は見当らない。したがって白葉枯病 細菌によるイネ葉の発病機構を考察する資料を得る目 的で研究を行なった。

本報告はイネ葉の主要構成成分である炭水化物, 窒
素化合物およびリン酸化合物につ、て, 感染による成 分含量の変動について実験した結果である。

\section{II. 実験材料および方法}

供試イネ品種は感受性の愛知旭である。苗は春日井 氏処方5)を一部修正した水耕液 $\left(\mathrm{FeCl}_{2}\right.$ のかわりにエ チレンジアミン 4 酢酸 $2 \mathrm{Na} 3.72 \mathrm{~g}, \mathrm{FeSO}_{4} \cdot 7 \mathrm{H}_{2} \mathrm{O} 2.78 \mathrm{~g}$. $1 \mathrm{~N}-\mathrm{NaOH}$ 液 $10 \mathrm{~m} l$ を蒸溜水で $100 \mathrm{~m} l$ とし，水耕液 $l$ 当たり $2.2 \mathrm{~m} l$ を添加した。水耕液は 100 倍 $\mathrm{HCl}$ 稀釈 液を用いて pH 5.5 に調製した。）を用い，ガラス室内 で育成した。水耕液は 1 週間ごとに交換した。感染率 を高め，さらに病斑を拡大させるために接種 10 日前 から水耕液中のカリウムを除き，窒素量を 2 倍とし

* 本論文の概要は昭和 46 年 10 月日本植物病理学会東北部会で発表した。

** 東北大学農学部 Faculty of Agriculture, Tohoku University, Sendai, Japan. 
た。供試菌は強病原性の Xanthomonas oryzae $\mathrm{H}$ 5809 である。脇本馬鈴蔗半合成培地 ${ }^{18)}$ を用い，2 日 間培養 (30C) した斜面培養試験管 1 本につき, $1 \mathrm{ml}$ の生理食塩水を加え, 振とうして得た細菌浮遊液を接 種液として用いた。

接種方法：穂ばらみ期の株を用い，主桿の止葉か ら逆にかどえて 2 葉と 3 葉を㬰験に用いた。半葉法と して各葉の片側葉身に基部から先端にわたり約 $2 \mathrm{~cm}$ の間隔で絹針 10 本の針束接種を行ない感染葉身とし た。また反対側葉身は生理食塩水で同様な接種操作を 行ない，これを非感染葉とした。30C の接種箱内に各 株を 48 時間保った。その後は温室に移し, 病斑を形 成させた。

接種後 $3,5,7$ 日の 3 回接種葉を採取した。毎回卜 レイシングペーパーを用いて病斑部を写し取り, それ を方眼紙に転写し, 病斑面積を切り取って科量し, 半 葉身面積に対する総病斑面積の割合を求めて, これを 病斑面積率とした。

分析のため採取した葉は, 分析に供するまで涷結保 存した。中肋を除去して健全葉身と罹病葉身に分け, 各々について，乾物重に換算して約 $1 \mathrm{~g}$ （葉身 50〜60 枚相当）について分析を行なった。なお接種葉の採取 時間は, 午前 10 時と定めて行なった。

炭水化物の分析は，村山ら 10) の方法によった。す なわら, 採取葉を細切し, 石英砂と共に $80 \%$ エ夕ノー ルを加えてパルプ状になるまで磨砕し, 加熱抽出後遠 心分離し, 上清を減圧濃縮, さらに除蛋白処理後, 一 部について Somogyi-Nelson 法1) でグルコースとし て定量, これを直接還元糖分画とした。また上記除蛋 白液の一部は硫酸で加水分解後同様に定量し, これを 全糖分画とした。さらに全糖と直接還元糖の差を非還 元糖とした。上記 $80 \%$ エタノール抽出後の残査は糊 化して, 過塩素酸で抽出を行ない, 抽出液の過塩素酸 濃度を $0.56 \mathrm{~N}$ に調製し, 加水分解, 中和後同様にグル コースとして定量し，これを粗でんぷん分画とした。 全炭水化物含量は葉約 $0.5 \mathrm{~g}$ を細切し, 石英砂と共に $0.7 \mathrm{~N}$ 塩酸を加えて乳鉢で磨砕し, 加水分解, 遠心分 離後上清を中和，除蛋白をして同様に定量した。この 炭水化物含量值から全糖と粗でんぷん含量值の和を差 引いたものをへミセルロース系炭水化物とした。

窒素化合物の分画は, 主に高橋ら ${ }^{15)}$ の方法によっ た。すなわち, 前記と同様に葉を細切し, 石英砂・水 と共に乳鉢で磨砕する。磨䂥液を遠心分離し, 残査は 数回水で洗涤, 上清を合して一定量とする。この一部 を分解フラスコにとり, 少量の硫酸カリウムを加えて
硫酸分解を行ない, Indophenol 法20)により水溶性全 窒素を定量した。別に上記上清の一部をとり，冨山 ら17) の方法によってトリクロル䣷酸 (TCA)による蛋 白沈殿操作を行ない，沈殿を遠心分離後 TCA 溶液で 洗滌し，前記と同様に沈殿を硫酸分解して窒素を定量 した。これを水溶性蛋白態窒素とする。アンモニア態 窒素は，上記上清の一部につき，アルカリ性で常温に よる通気操作を 24 時間行なって留出するアンモニア を捕集し，同様に窒素を定量した。アミド態窒素は， 上清の一部を硫酸で加水分解後アルカリ性とし, 以下 アンモニア態窒素定量の場合と同様に通気操作を行な い, 留出してくるアンモニアを捕集し, 同じく窒素を 定量する。この定量值よりアンモニア態窒素定量値を 差引いたものをアミド態窒素とした。水溶性全窒素か ら, 水溶性蛋白態窒素, アミド態窒素およびアンモ二 ア態窒素の定量值を差引いた値を残余窒素とする。別 に葉約 $0.5 \mathrm{~g}$ を硫酸分解し，同様に定量を行ない，こ れを全窒素とし，この全窒素と水溶性全窒素との差を 非水溶性蛋白態窒素とした。

窒素化合物のうち水溶性蛋白の分画については下記 の様に行なった。すなわら, 葉約 $1 \mathrm{~g}$ を細切し, 冷却 下で石英砂および $0.1 \mathrm{M}$ トリス塩酸緩衝液 ( $\mathrm{pH}$ 8.0) を 加えて磨砕し， $105,000 \times g$ で2時間超遠心分離を行な った。上清を Diaflo XM-100 および PM-30 で処理 し, 水溶性蛋白質を分子量 10 万以上, 10 万-3 万およ び 3 万以下に分画した。分子量 10 万以上の蛋白質分 画の 5ち, Jakoby ら4) の方法によって, $\left(\mathrm{NH}_{4}\right)_{2} \mathrm{SO}_{4}$ とエタノールによる沈殿操作をくり返して Fraction I 蛋白質の粗抽出物を得た。各分画の蛋白質含量は Folin 試薬3)を用いて測定し，牛血清アルブミンに換 算した。

リン酸化合物は，葉 $1 \mathrm{~g}$ の細切片を石英砂と共に冷 10\% TCA 溶液を加えて冷却下で磨砕し, Schneider ${ }^{12)}$ の方法によって, 遠心分離後, 上清は酸溶性リン分画 とし, 沈殿についてエタノール・エーテル混液, TCA 溶液および $\mathrm{NaOH}$ 溶液による抽出を行ない，脂質り ン，核酸リン，蛋白リンおよび不溶性リンに分画した。 各分画は湿式灰化後, 高橋22) の方法で無機リンとし て定量した。酸溶性リン分画の一部を灰化せず陵らに 定量したものを無機リン分画とした。また，葉 $0.5 \mathrm{~g}$ を湿式灰化後同様に定量し，これを全リンとした。

\section{III. 実験結果}

\section{(1) 病斑形成の経過}

前記の実験条件下では接種後 2 日目に一部の接種葉 
で，3 日目にはほとんどの接種葉で葉脈に並行したス ジ状の水浸状淡黄色病斑が形成した。各病斑は相互に 接することはなく，また病斑部と健全部との境界も不 明瞭であった。接種葉 15 枚の平均病斑面積率は約 $14 \%$ (病斑 1 個の平均面積は約 $25 \mathrm{~mm}^{2}$ ) であった。接 種後 5 日目には, 病斑は黄色となり, 多くの病斑では, その両端が互に融合するようになり，また健全部との 境界は明瞭となった。平均病斑面積率は約 $33 \%$ に増 大した。接種後 7 日目では, 病斑は橙黄色を呈し，一 部の葉身では葉縁が灰白色となった。各病斑は，完全 に融合して連らなり，健全部は中胁に沿った部分での み観察された。平均病斑面積率は約 65\% であった。 なお，中肋の反対側の非接種葉身では，特に肉眼的異 常は発見できなかった。

\section{(2) 炭水化物の変動}

第 1 表に示すよ 5 に，全炭水化物は，接種後の日時 が経過するにしたがい，わずかに堌加する傾向にある が，罹病葉身は健全葉身比比べて含有率が低かった。 直接還元糖，非還元糖など全糖含有率は，罹病の初期 において健全葉より若干高いが，後期では逆の傾向を 示した。へミセルロース系炭水化物は，全炭水化物の
場合と同様に，やはり羅病葉身で低下している。全炭 水化物中に占めるへミセルロース系炭水化物の割合は 約 $60 \%$ で，この減少が直接全炭水化物含有率に影響を 与えたものであろう。へミセルロース系炭水化物の内 容は明確でなく，へミセルロースのほかにペントザ ンセルロースなどと共に細胞壁の構成成分と考えられ ており，この含有率低下は䍜病組織での細胞壁の変化 を推定させる。粗でんぷ翰はいずれの場合でも，非常 に低濃度でのみ検出されたが，罹病葉身で沙常に高い 傾向が認められた。本報での粗でんぷん定量法はでん ぷんの注かにデキストリン様の多糖類，さらには細胞 壁の構成成分の一部も含まれて来る。また，病原細菌 の生産する粘性多糖類も粗でんぷんとして含まれた可 能性もある。

これらを総合して判断すると，罹病により組織を構 成している炭水化物, 特に細胞壁の構成成分に变化 が生じでくる。一方，正常な代謝系が分解過程に移行 し，その結果が全糖などの增加として反映されたもの と考えられる。今後は，これらの現象と関連する酵素 活性を測定し，それを裏付ける必要があると考えら れる。

第 1 表 椎病にともなら炭水化合物の变動

\begin{tabular}{|c|c|c|c|c|c|c|}
\hline \multirow{2}{*}{ 接 種後の日数 } & \multicolumn{2}{|c|}{3} & \multicolumn{2}{|c|}{5} & \multicolumn{2}{|c|}{7} \\
\hline & 健全葉 & 雀 病 葉 & 健全葉 & 罹 病 葉 & 健全葉 & 罹 病 葉 \\
\hline 全炭水化物 & $23.2^{\mathrm{a}}$ & $23.0^{\mathrm{a}}(1.0)^{\mathrm{b}}$ & 25.1 & $24.7(1.0)$ & 26.2 & $25.1(1.0)$ \\
\hline 全 & 9.3 & $10.2\langle 1.1)$ & 9.6 & $10.1(1.1)$ & 102 & $9.7(1.0)$ \\
\hline 直接 還 元 糖 & 3.0 & $3.4(1.1)$ & 2.9 & $3.0(1.0)$ & 3.6 & $3.5(1.0)$ \\
\hline 非 還 元 糖 & 6.3 & $6.8(1.1)$ & 6.7 & $7.1(1.1)$ & 6.6 & $6.2(0.9)$ \\
\hline 粗でんぷん & 0.2 & $0.4(2.0)$ & 0.2 & $0.3(1.5)$ & 0.3 & $0.5(1.7)$ \\
\hline へミセルロ一ス系炭水化物 & 13.7 & $12.4(0.9)$ & 15.3 & $14.3(0.9)$ & 15.7 & $14.9(1.0)$ \\
\hline
\end{tabular}

a 乾物重当りの百分率 b 健全葉に対する比

\section{（3）窒素化合物の変動}

結果を第 2 表に示した。罹病葉身においては全窒 素, 水溶性全窒素ともに含有率が低下している。酵素 などのイネ生理に重要な影響をもつ蛋白質は水溶性蛋 白態窒素分画に属するが，これは罹病の影響を受けや すく，急激に低下する。これに対し，アンモニア態窒 素の含有率は他形態の窒素に比較して，元来最も低い が，他形態窒素含有率が罹病で低下するのに対し，む しろ増加する傾向が認められた。非水溶性蛋白態窒素 は全窒素の大部分を占めているが，全窒素と同様に， 実験期間中減少する傾向を示している。その含有率は 羅病葉身で低く，葉緑粒など細胞構成成分が破壊され
て行くことを推定させる。アンモニア態窒素の増加 は，これら蛋白質の分解産物と考劣られる。坂本 ${ }^{11)} に$ よれば，イネ体内に蓄積されたアンモニアは，細胞原 形質に有害な作用をおよぼすので，本病においても， 遊離アンモニアの増加が，罹病程度の増大に関係する 要因の一つとも思われる。一方, 残余窒素はア之ノ酸 がその主体と考えられるが，アミド態窒素と共に罹病 葉身に拈いて，増加が認められない。これはアミド， アミノ酸がアンモニア態窒素と比較して, 本病細菌に とり込まれ易いか，あるいは他組織に転流され易いた めであろう。 
第 2 表 罹病にともなら窒素化合物の変動

\begin{tabular}{|c|c|c|c|c|c|c|}
\hline \multirow{2}{*}{ 接種後の日数 } & \multicolumn{2}{|c|}{3} & \multicolumn{2}{|c|}{5} & \multicolumn{2}{|c|}{7} \\
\hline & 健全葉 & 罹 病 葉 & 健全葉 & 罹 病 葉 & 健全葉 & 罹 病 葉 \\
\hline 全 窒 素 & $3.85^{\mathrm{a}}$ & $3.73^{\mathrm{a}}(1.0)^{\mathrm{b}}$ & 3.67 & $3.01(0.8)$ & 3.32 & $2.32\langle 0.7\rangle$ \\
\hline 水溶性全窒素 & 0.65 & $0.58(0.9)$ & 0.60 & $0.50\langle 0.8\rangle$ & 0.61 & $0.46(0.8)$ \\
\hline 水溶性蛋白態窒素 & 0.18 & $0.11(0.6)$ & 0.17 & $0.07(0.4)$ & 0.16 & $0.05(0.3)$ \\
\hline アンモニア態窒素 & 0.05 & $0.06(1.2)$ & 0.05 & $0.12(2.4)$ & 0.06 & $0.11(1.8\rangle$ \\
\hline アミド態窒素 & 0.06 & $0.06(1.0)$ & 0.05 & $0.04(0.8)$ & 0.05 & $0.05(1.0)$ \\
\hline 残 余 窒 素 & 0.36 & $0.35(1.0)$ & 0.33 & $0.27(0.8)$ & 0.34 & $0.25(0.7)$ \\
\hline 非水溶性蛋白態窒素 & 3.20 & $3.15(1.0)$ & 3.07 & $2.51(0.8)$ & 2.71 & $1.86(0.7)$ \\
\hline
\end{tabular}

a 乾物重当りの百分率 b 健全葉に対寸る比

\section{（4）水溶性蛋白質組成の変動}

第 2 表の結果から，罹病葉身に打いて水溶性蛋白態 窒素の減少が特に顕著に認められたので，どのように 蛋白質組成が変化しているかを知るため，分子量によ る分画を試みた。結果を第 3 表に示した。分画操作に おいて他分画成分の相互混入を防ぐため，各分画操作 を数回くり返するなど充分注意したが，Diafloによる 分画は厳密なものとはいえず，いく分かの混入はさけ られない。しかし，この分画操作は Sephadex など によるカラムクロマトグラフィー，超遠心分離による 分画と本質的には同じであり，本実験目的には充分有
用であると思われる。第3 表の結果によると，罹病葉 身の蛋白質の5ち分子量 10 万以上の高分子蛋白質の 減少がいちぢるしく，特に Fraction I 蛋白質に相当 する分画の減少が顕著であった。Fraction I 蛋白質 は，最近その本体がカルボキシディスムターゼである といわれ，この分画の減少は罹病葉での光合成の低下 が予想される。一方，これら分子量 10 万以上の蛋白 質分画の減少に対して, 分子量 $3 \sim 10$ 万と 3 万以下の 蛋白質分画が増大しており，䍜病により高分子蛋白質 の低分子化が起っていると考えられる。

第 3 表 篗病にともなう水溶性蛋白質組成の変動

\begin{tabular}{|c|c|c|c|c|c|c|}
\hline \multirow{2}{*}{ 接種 後の日数 } & \multicolumn{2}{|c|}{3} & \multicolumn{2}{|c|}{5} & \multicolumn{2}{|c|}{7} \\
\hline & 健全葉 & 䍜病葉 & 健全葉 & 懽病葉 & 健全葉 & 篗病葉 \\
\hline 分子量 10 丁以上分画 & 37.6 & 32.9 & 36.3 & 30.2 & 38.5 & 26.4 \\
\hline Fraction I 蛋白質分画 & $(36.7)$ & $(32.2)$ & $(35.8)$ & ( 3.5$)$ & $(37.6)$ & $(0.6)$ \\
\hline 分子量 3 10 万分画 & 19.5 & 21.3 & 20.2 & 18.9 & 19.0 & 12.4 \\
\hline 分子量 3 万以下分画 & 42.9 & 45.8 & 42.5 & 50.9 & 42.5 & 61.2 \\
\hline
\end{tabular}

数值は全水溶性蛋白質に対する各分画の百分率

第 4 表 罹病にと夕ならリン酸化合物の变動

\begin{tabular}{|c|c|c|c|c|c|c|}
\hline \multirow{2}{*}{ 接種後の日数 } & \multicolumn{2}{|c|}{3} & \multicolumn{2}{|c|}{5} & \multicolumn{2}{|c|}{7} \\
\hline & 健全葉 & 罹 病 葉 & 健全葉 & 罹 病 葉 & 健全葉 & 罹 病 葉 \\
\hline 全 & $0.18^{\mathrm{a}}$ & $0.22^{\mathrm{a}}(1.2)^{\mathrm{b}}$ & 0.18 & $0.24(1.3)$ & 0.17 & $0.18(1.1)$ \\
\hline 酸溶性リン & 0.13 & $0.15(1.2)$ & 0.13 & $0.13(1.0)$ & 0.12 & $0.10(0.8)$ \\
\hline 無 機 リン & 0.09 & $0.10(1.1)$ & 0.09 & $0.08(0.9)$ & 0.09 & $0.07(0.8)$ \\
\hline 脂 質 リン & 0.01 & $0.01(1.0)$ & 0.01 & $0.02(2.0)$ & 0.01 & $0.01(1.0)$ \\
\hline 核 酸 リン & 0.02 & $0.02(1.0)$ & 0.02 & $0.03(1.5)$ & 0.02 & $0.02(1.0)$ \\
\hline 蛋 白 リン & 0.01 & $0.01(1.0)$ & 0.01 & $0.01(1.0)$ & 0.01 & $0.01(1.0)$ \\
\hline 不溶性りン & 0.01 & $0.03(3.0)$ & 0.01 & $0.05(5.0)$ & 0.01 & $0.04(4.0)$ \\
\hline
\end{tabular}




\section{（5）リン酸化合物の変動}

罹病にともなうリン酸化合物の変動を第 4 表に示し た。全リンは実験期間を通じて大きな变動はなかった が，罹病葉身では健全葉身比比較して，常に含有率が 高い傾向にあった。この傾向は不溶性りンで顕著で, 常に 4 5 倍の含有率を保っている。蛋白リンは罹病, 健全葉身間で差がなく, 脂質リン, 核酸リンは含有率 が高い。酸溶性リン, 無機リンは大体同じ様な消長を たどり, 初期の罹病葉身で含有率が高く, 病状が進行 するのにしたがって逆の傾向を示す上うになる。酸溶 性リンは，エネルギー代謝なぞに必須な各種リン酸化 合物を含み, 罹病初期に含有率が增加している。この ことは渡辺ら ${ }^{19)}$ の稲白葉枯病感染初期葉で呼吸の高 まりが観察されたことと一致する。ただし，いずれの 場合飞も罹病葉の分析飞扮いては混在している病原細 菌も共に分析しているわけであり, 酸溶性リンなどの 增加が稲葉組織単独のものであるかどうかは明白で ない。

\section{VI. 論義}

イネ白葉枯病に感染した感受性品種, 愛知旭を用い, 発病にともなら葉内成分について感染後経日的に測定 した。したがって抵抗反応が小さく, 病斑の拡大しや すい状態での成分变動を示するのである。接種 3 日後 の罹病初期葉に打いて, 炭水化物では直接還元糖, 非 還元糖など全糖が若干增加しておう, 窒素化合物では 水溶性蛋白態窒素の減少とアンモニア態窒素の増加, リン酸化合物では酸溶性リン酸化合物の増加, 特に無 機リン酸の増加などが特徵的である。一般に蛋白質が 分解減少して行くときは蛋白質がア之, 酸に分解し, さらにア之ノ酸が有機酸とアンモニアに分解する過程 を経るが，イネ音葉枯病感染葉の場合も水溶性蛋白質 の減少, アンモニア態窒素の増加が観察されることか ら同様の過程を経ているものと思われる。さらに減少 が顕著な水溶性蛋白質は, 病症の進展にともない低分 子化していることがわかる。これら分解反応は本病原 細菌の生産する蛋白分解䤉素が関与しているものと思 われるが，寄主体側泊己自己解作用としての蛋白質 分解反応が存在するから, 現段階ではどちらかが主体 的であるか不明である。同様のことは，直接還元煻や 非還元糖などの增加から炭水化物の場合にも考兄られ る。リン酸化合物のうち, 酸溶性リンの増加は罹病組 織での呼吸上昇を推定させるが，その場合無機リンの 增加と関連して, リン酸を効果的に有機化する作用は 低下しているものと予想される。
接種 7 日後の罹病後期葉では，汪とんどの諸成分が 健全葉より低下して抢り, 細胞の代謝を維持する種々 の生理機能があらゆる面で低下し,ささらに構造の構成 成分などの崩壊も進行する。接種 5 日後の罹病中期葉 では䍜病初期葉の分析值とかなり類似した結果を示 し, この時期を境にして, より急速に分解過程が進行 するものと思われた。

以上の結果を病斑面積率と関連させて考察すると， これら諸成分の増減が病斑部でだけ生じている現象な らば，その增減の比率は病斑面積率と一致するはずで ある。ところが，初期葉では大体一致しているが，曜 病中期と後期葉では必ずしも一致しない。ま芯の若 化にともなって最子敏感に減少するといわれている Fraction I 蛋白質は，本病原細菌には存在していな いと考えられるから，この減少の割合が最も良く病玟 面積率と一致するはずである。Fraction I 蛋白質の 減少率と病斑面積率を比較してみると羅病初期葉では 一致しているが，罹病中期および後期葉では病斑面積 率を上まわった Fraction I 蛋白質の減少が認められ， この時期には病斑部以外の健全部でも罹病の影響を受 けていることが予想される。

\section{V. 摘 要}

本報告は稲白葉枯病罹病にともなら水稲葉の炭水化 物，窒素化合物，リン酸化合物の変動について述べた。

1) 炭水化物 罹病初期で全糖の含有率增加が認め られたが，罹病後期では全糖の含有率は省しろ健全葉 より低下する。粗でんぷんはいずれの時期でも㒑病葉 で含有率が高い。また, 全炭水化物抢よびへミセル口 一ス系炭水化物は罹病に上り若干低下する。

2）窒素化合物 䍜病葉では水溶性蛋白態窒素拈よ び非水溶性蛋白態窒素の低下が顕著で, 逆にアンモニ ア態窒素の增加が認められた。罹病が進行するにした がって，全窒素が減少した。水溶性蛋白質を分子量の 大小に分画して定量すると, 分子量 10 万以上の, 特 飞 Fraction I 蛋白質部分の減少が観察され, 一方分 子量 3 万以下の低分子蛋白質の割合が增加した。

3）リン酸化合物 䍜病初期で酸溶性リン, 無機リ ンの増加が認められた。全リン, 不溶性リンは実験期 間中では常に罹病葉で含有率が高い傾向にあった。

\section{文献}

1）福井作蔵 (1969). 還元糖の定量法. 東京, pp. 10.

2）後藤和夫ら (1953). 日植病報 $18: 82$.

3）萩原文二ら (1964)。醉素研究法 II（赫堀四郎䋧） 
東京, pp. 237.

4) Jakoby, W. B. et al (1956). J. Biol. Chem. $218: 811-822$.

5）春日井新一郎 (1939). 土肥誌 $13: 669-822$.

6) 近藤源吉 - 香村敏郎 (1953). 愛知農試彙報 8 : 21-34.

7) 久原重松・関谷直正 (1957). 日植病報 $22: 9$.

8) 水上武幸 (1961). 佐賀大学農学部彙報 13:1-85.

9）向秀夫・伊阪実人 (1964). 日植病報 29:13-19.

10）村山 登ら (1955). 農技研報告 B 4: 123-166.

11）坂本正幸 (1968). 坂本教授還暦記念論文集. 似 台, pp. 93.

12) Schneider, W. C. (1945). J. Biol. Chem. 161 :
$293-303$.

13）諏訪隆之 (1962). 日植病報 $27: 165-171$.

14）田上義也ら (1957). 日植病報 $22: 8$.

15）高橋治助5 (1955). 農技研報告 B 4: 85-122.

16) 田中行久 (1963). 九大農学芸誌 20: 151-155.

17）冨山宏平ら (1955)。 日植病報 $20: 59$.

18) 脇本 哲 (1955). 九大農学芸誌 $15: 151-160$.

19）渡辺実ら (1968). 日植病報 $34: 186$.

20）八木国夫・奥田 潤 (1959). 蛋・核・酵 4:139141.

21）山中 達ら (1952). 日植病報 16: 191.

22) 吉川春寿 - 高橋泰常 (1958). 燐酸代謝実験法. 東 京, pp. 29. 